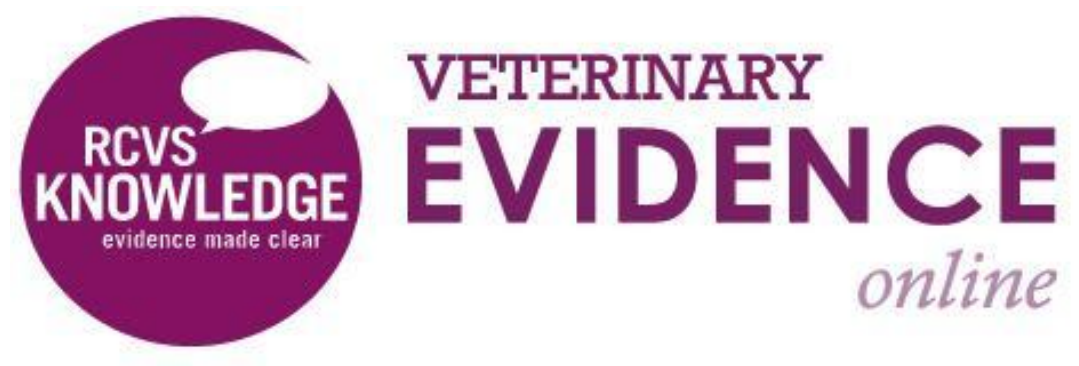

\title{
Do Palliative Steroids Prolong Survival in Dogs With Multicentric Lymphoma?
}

\section{A Knowledge Summary by}

Clare M Knottenbelt BVSc MSc DSAM MRCVS ${ }^{1 *}$

\footnotetext{
${ }^{1}$ College of Medical, Veterinary and Life Sciences, University of Glasgow

Corresponding Author (Clare.Knottenbelt@glasgow.ac.uk)
}

ISSN: 2396-9776

Published: 02 Feb 2018

in: Vol 2, Issue 1

DOI: http://dx.doi.org/10.18849/ve.v3i1.96

Reviewed by: Simon Bate (BVMS CertSAM MRCVS) and Adam Swallow (BVSc AFHEA MRCVS)

Next Review Date: 02 Feb 2020 


\section{KNOWLEDGE SUMMARY}

\section{PICO question}

In dogs with naturally occurring multicentric B cell lymphoma does treatment with glucocorticoids alone extend survival time when compared to no treatment?

Clinical bottom line

There is weak evidence, due to insufficient studies with untreated control groups, regarding the impact on survival of prednisolone treatment in dogs with multicentric lymphoma.

From the papers identified from the search functions used for the clinical question remission in uncontrolled trials was reported following prednisolone treatment. Details of which can be found in other sections of this paper.

\section{Clinical Scenario}

An eight year old male neutered Labrador presents with multicentric lymphadenopathy. He is otherwise well. Staging (abdominal and thoracic imaging plus bone marrow aspirates) confirm that he is stage $3 a$ (multicentric lymph node involvement without evidence of systemic illness). Routine bloods are normal. The owner does not want to use chemotherapy due to the health and safety implications. You have offered prednisolone treatment and explained the side effects. The owner would like to know the prognosis and average survival time if she opts for treatment with prednisolone alone.

\section{Summary of the evidence}

\begin{tabular}{|c|c|}
\hline Population: & $\begin{array}{l}\text { Dogs with lymphoma recruited via Veterinary Cancer Society 2006- } \\
2008 \text { and with confirmed histopathology }\end{array}$ \\
\hline Sample size: & 944 dogs with lymphoma. Survival data only available for 456 dogs. \\
\hline Intervention details: & $\begin{array}{l}\text { Dogs with lymphoma of varying types (high grade, intermediate } \\
\text { grade and low grade) treated with various types of chemotherapy or } \\
\text { with prednisolone alone or not treated. Drug doses and duration are } \\
\text { not specified. The paper does not state how many dogs were in } \\
\text { each of the lymphoma type groups, however there is limited } \\
\text { reference to the numbers of dogs in some of the treatment groups. } \\
\text { This reflects the focus on survival for the group as a whole rather } \\
\text { than in respect of differing treatment regimes. }\end{array}$ \\
\hline Study design: & Descriptive case series (retrospective) \\
\hline Outcome studied: & Survival in days \\
\hline $\begin{array}{l}\text { Main findings: } \\
\text { (relevant to PICO question): }\end{array}$ & $\begin{array}{l}\text { Proportional hazards regression models were used to assess relative } \\
\text { risk of death and reported as Hazard ratios (HR) and } 95 \% \text { Confidence }\end{array}$ \\
\hline
\end{tabular}




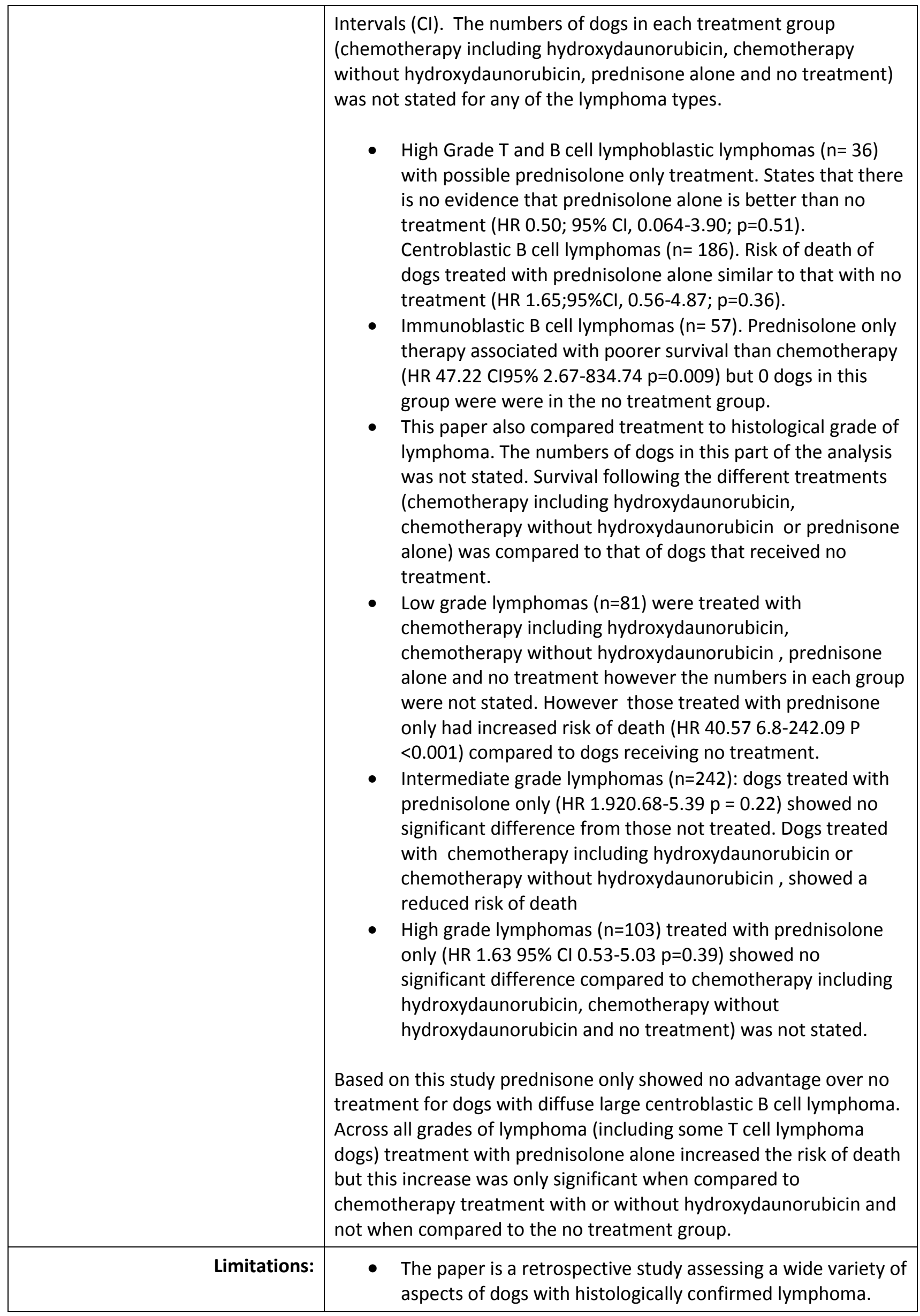




\begin{tabular}{|l|l|}
\hline These include classification of cell type (T vs B, mitotic rate \\
and histological types.) It aims to show how survival varies in \\
different treatment regimens and relate this to disease \\
variables. \\
Cases were recruited through a Veterinary Cancer Society \\
newsletter which could result in loss of patients from \\
veterinary practices without a special interest in cancer \\
treatment which would mean there might be fewer patients \\
in the prednisolone alone or no treatment groups. There \\
was an ongoing study into one treatment regime so this may \\
have been over-represented. \\
The authors state that the majority of cases came from the \\
USA with a few from Europe and Canada. It is possible that \\
there were variations in treatment choices or histological \\
diagnosis in the cases from Europe however there is no \\
detail provided about the patient numbers involved. \\
Patients were only included where there was histological \\
confirmation and immunohistochemistry had been \\
performed. Again this might reduce recruitment of patients \\
whose owners were unwilling or unable to perform these \\
tests or where a diagnosis was reached by cytology alone. \\
Survival time was recorded for all patients and those who \\
remained alive at the time of the study were censored. \\
As this was a retrospective study, patients were allocated to \\
a particular treatment option based on clinician and owners \\
preference. It is not clear from the paper if cases from \\
particular practices or regions had differing treatment \\
regimes. \\
There is no reporting of the dose of prednisolone used for \\
the prednisolone alone group or any reporting of the \\
chemotherapy doses used. \\
Similarly there is no reporting of the numbers of dogs in \\
each treatment group within each category. This reflects the \\
focus on survival for the group as a whole rather than in \\
respect of differing treatment regimes. \\
\hline
\end{tabular}

\begin{tabular}{|r|l|}
\hline \multicolumn{2}{|l|}{ Tozon (2006) } \\
\hline Population: & Dogs with lymphoma diagnosed by cytology \\
\hline Sample size: & 39 dogs \\
\hline Intervention details: & $\begin{array}{l}13 \text { dogs on differing chemotherapy regimes: COP protocol ( } \mathrm{n}=6), \\
\text { COPA protocol }(\mathrm{n}=4) \text { doxorubicin }(\mathrm{n}=2) \text { and methylprednisolone } \\
(\mathrm{n}=1) \text {. Drug doses and duration were not stated }\end{array}$ \\
\hline Study design: & Descriptive case series \\
\hline Outcome studied: & $\begin{array}{l}\text { Occurrence of different cyto-morphological diagnoses and how sex, } \\
\text { clinical stage and treatment choice affects first remission time (days) } \\
\text { and survival time (days) of patients undergoing differing regimes of } \\
\text { treatment. }\end{array}$ \\
\hline
\end{tabular}




\begin{tabular}{|c|c|}
\hline $\begin{array}{l}\text { Main findings: } \\
\text { (relevant to PICO question): }\end{array}$ & $\begin{array}{l}\text { Cytomorphological analysis was similar to previous reports with high } \\
\text { malignant lymphoma in } 25 \text { dogs, intermediate grade lymphoma in } \\
13 \text { dogs and low malignant lymphoma in } 1 \text { dog. } \\
\text { There is no information on outcome in } 26 \text { dogs and it is not clear if } \\
\text { they received any treatment. } \\
13 \text { dogs were treated these comprised } 6 \text { dogs with high grade, } 6 \\
\text { dogs with intermediate and } 1 \text { dog with low grade. Details on which } \\
\text { treatment each dog received are provided but the numbers in each } \\
\text { subgroup are two small to draw any further information on the } \\
\text { survival times associated with each lymphoma type. } \\
\text { However within all grades of tumour treated median survivals } \\
\text { were: } \\
\text { COP-treated dogs ( } n=6 \text { ) } 160 \text { days, } \\
\text { COPA treated dogs ( } n=4) 225 \text { days } \\
\text { Doxorubicin treated dogs ( } n=2 \text { ) were alive at } 90 \text { days } \\
\text { Methylprednisolone alone ( } n=1 \text { ) } 240 \text { days } \\
\text { Median first remission was longer in females ( } n=6 ; 215 \text { days) than } \\
\text { males ( } n=7 ; 159 \text { days) }\end{array}$ \\
\hline Limitations: & $\begin{array}{l}\text { - Only one patient out of } 39 \text { received prednisolone alone. } \\
\text { - Authors do not state how cases were selected or give any } \\
\text { inclusion or exclusion criteria for this study }\end{array}$ \\
\hline
\end{tabular}




\begin{tabular}{|c|c|}
\hline Population: & $\begin{array}{l}\text { Dogs and cats with lymphoma examined at Ohio State University } \\
\text { Veterinary Clinic 1959-1965 }\end{array}$ \\
\hline Sample size: & 32 dogs and 6 cats \\
\hline Intervention details: & $\begin{array}{l}\text { Comparison of } 4 \text { different treatment regimens: cyclophosphamide } \\
\text { ( } n=4 \text { dogs), prednisolone alone ( } n=6 \text { dogs), chlorambucil ( } n=9 \text { dogs), } \\
\text { chlorambucil combined with prednisolone at the same doses as the } \\
\text { individual drugs ( } n=7 \text { dogs) and no treatment ( } n=6 \text { dogs) on mean } \\
\text { survival time. } \\
\text { The following dosage regimes were used: } \\
\text { Cyclophosphamide } 0.3 \mathrm{mg} / \mathrm{kg} / \text { day for } 14 \text { days followed by } 14 \text { days } \\
\text { with no treatment } \\
\text { Prednisolone } 0.5 \mathrm{mg} / \mathrm{kg} / \text { day for } 14 \text { days followed by } 7 \text { days without } \\
\text { treatment and the } \mathrm{schedule} \text { then repeated. } \\
\text { Chlorambucil } 0.2 \mathrm{mg} / \mathrm{kg} / \text { day for } 14 \text { days followed by } 14 \text { days without } \\
\text { treatment and the schedule then repeated. } \\
\text { Prednisolone } 0.5 \mathrm{mg} / \mathrm{kg} / \text { day for } 14 \text { days followed by chlorambucil } \\
0.2 \mathrm{mg} / \mathrm{kg} / \text { day for } 14 \text { days and the schedule then repeated. }\end{array}$ \\
\hline Study design: & Descriptive case series \\
\hline Outcome studied: & Objective - Survival time in weeks \\
\hline $\begin{array}{l}\text { Main findings: } \\
\text { (relevant to PICO question): }\end{array}$ & $\begin{array}{l}\text { - } 6 \text { dogs were given no treatment and mean survival time was } \\
2.5 \text { weeks and disease was extensive in } 4 \text { of the dogs. } \\
\text { However grade was not mentioned. } \\
\text { - Prednisolone regime was administered to } 6 \text { dogs however } \\
\text { one of these also received radiotherapy on one occasion. } \\
\text { Survival time ranged from 1-7.5 months with a mean of } 2.5 \\
\text { months. } \\
\text { Of the } 6 \text { dogs and } 2 \text { cats that received prednisolone alone } \\
\text { only } 7 \text { had a temporary reduction in node size. }\end{array}$ \\
\hline Limitations: & $\begin{array}{l}\text { - The paper is a retrospective study but does not state how } \\
\text { patients were identified or if any cases were excluded. } \\
\text { Diagnosis was based on a combination of clinical signs } \\
\text { (anorexia, depression, weight loss, anaemia and generalized } \\
\text { lymphadenopathy) haematology results and a biopsy of } \\
\text { tonsil or popliteal lymph node or bone marrow which would } \\
\text { be acceptable assuming all patients had all three criteria } \\
\text { assessed. This is not stated in the paper. Furthermore the } \\
\text { paper does not state whether dogs had all or some of these } \\
\text { symptoms and whether there was a difference in the } \\
\text { presentation of dogs and cats. } \\
\text { - The paper does not specify the stage/sub stage of the cases } \\
\text { reported except to state that the patients that had no } \\
\text { treatment had widespread disease. } \\
\text { Mean survival was reported rather than median which given } \\
\text { the low numbers of cases is far from ideal. }\end{array}$ \\
\hline
\end{tabular}




\begin{tabular}{|l|l|}
\hline - & Paper does not state the survival time of 1 dog that also \\
received radiation therapy and does not state which of the 6 \\
dogs and 2 cats did not get a reduction in node size. There is \\
no indication if location or grade of disease affected this \\
finding. \\
$\begin{array}{l}\text { Regime is not continuous prednisolone as usually } \\
\text { recommended in current veterinary practice across the } \\
\text { world. }\end{array}$ \\
\hline
\end{tabular}

\begin{tabular}{|c|c|}
\hline \multicolumn{2}{|l|}{ Squire (1973) } \\
\hline Population: & $\begin{array}{l}\text { Dogs with naturally occurring lymphoma recruited from local } \\
\text { veterinary practices. }\end{array}$ \\
\hline Sample size: & 100 dogs. \\
\hline Intervention details: & $\begin{array}{l}\text { Comparison of } 4 \text { different chemotherapeutic treatment schedules : } \\
\text { 1. Prednisone } 2 \mathrm{mg} / \mathrm{kg} / \text { day orally for } 7 \text { days followed by } 1 \\
\mathrm{mg} / \mathrm{kg} / \text { day thereafter ( } \mathrm{n}=49 \text { ) } \\
\text { 2. Prednisone as above plus cyclophosphamide } 5 \mathrm{mg} / \mathrm{kg} / \text { day } \\
\text { orally for } 7 \text { days followed by } 2.5 \mathrm{mg} / \mathrm{kg} \text { thereafter ( } \mathrm{n}=34 \text { ) } \\
\text { 3. Vincristine } 0.03 \mathrm{mg} / \mathrm{kg} \text { intravenously on day } 1 \text { and } 8 \text {. } \\
\text { Prednisone } 1 \mathrm{mg} / \mathrm{kg} / \text { day orally on days } 1 \text { and } 8 \text { and days } 9 \text { - } \\
\text { 21. Cyclophosphamide } 5 \mathrm{mg} / \mathrm{kg} / \text { day on days } 2-7 \text {. Regime } \\
\text { repeated every } 14 \text { days ( } \mathrm{n}=19 \text { ) } \\
\text { 4. Vincristine } 0.03 \mathrm{mg} / \mathrm{kg} \text { intravenously on day } 1 \text { and } 8 \text {. } \\
\text { Prednisone } 2 \mathrm{mg} / \mathrm{kg} / \text { day orally on days } 1 \text { and } 8 \text { followed by } 1 \\
\mathrm{mg} / \mathrm{kg} / \text { day on days } 9-21 \text {. Cyclophosphamide } 5 \mathrm{mg} / \mathrm{kg} / \text { day on } \\
\text { days } 15-21.6-\mathrm{mercaptopurine} 5 \mathrm{mg} / \mathrm{kg} / \text { day on days } 15-21 \text {. } \\
\text { Regime repeated every } 30 \text { days ( } \mathrm{n}=25 \text { ) } \\
\text { Dogs that failed to respond to one regime were moved to } \\
\text { treatment schedules } 2 \text { or } 3 \text { and then reported in that group }\end{array}$ \\
\hline Study design: & Non-randomised controlled trial \\
\hline Outcome studied: & $\begin{array}{l}\text { Mean objective remission duration in days (number of days before } \\
\text { regime failed to maintain complete remission }(C R) \text { or partial } \\
\text { remission }(P R \text { ) despite drug-induced toxicity. Survival measured as } \\
\text { number of days from initial presentation until natural death or } \\
\text { euthanasia in terminal disease. }\end{array}$ \\
\hline $\begin{array}{l}\text { Main findings: } \\
\text { (relevant to PICO question): }\end{array}$ & $\begin{array}{l}\text { - This study excluded } 18 \text { dogs that died or were euthanased } \\
\text { due to advanced disease or an unsatisfactory response to } \\
\text { therapy within } 14 \text { days of admission from the survival and } \\
\text { remission duration data. } \\
\text { - Of the } 49 \text { dogs on prednisolone only } 20 \text { ( } 41 \% \text { ) achieved } \\
\text { complete remission with a mean objective remission time of } \\
53 \text { days (range } 14-210 \text { days). Remission induction rapid and } \\
\text { usually reached its maximum at } 7 \text { days but was often partial } \\
\text { within } 72 \mathrm{~h} \text {. Partial remissions were not reported. }\end{array}$ \\
\hline
\end{tabular}




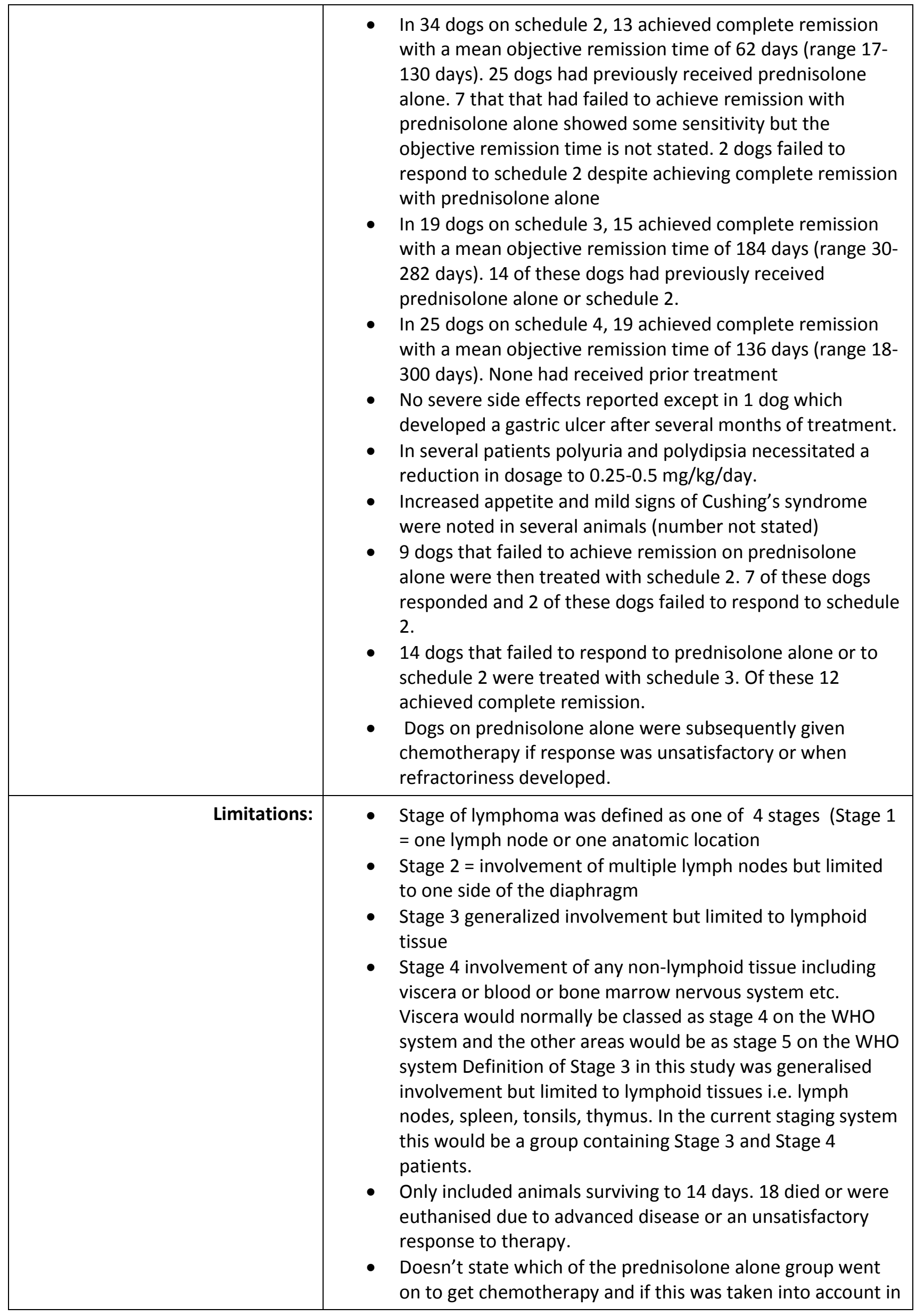




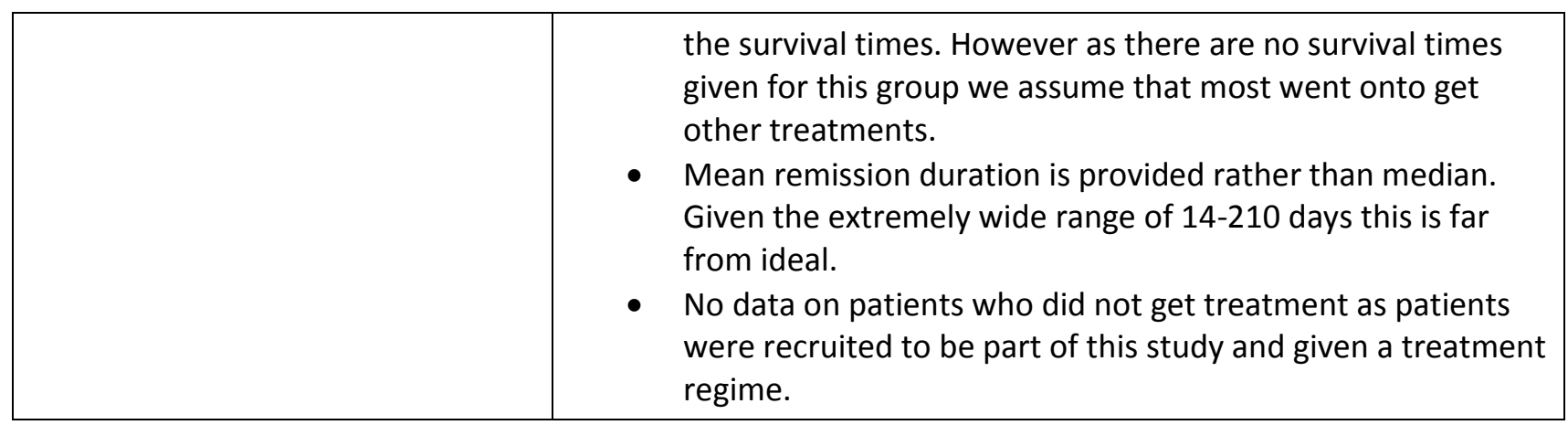

\section{Appraisal, application and reflection}

There is limited data on this topic with papers reporting findings in relatively small numbers of dogs. Unfortunately the paper that most closely answers the clinical question (Mortier et al., 2012) was only available as an abstract and therefore could not be fully reviewed. This study suggested that dogs could achieve remission for up to 210 days on prednisolone alone (median of 32 days). This is similar to the findings of Brick et al. (1968) and their reported survival times of 1-7.5 months with a cyclical administration of prednisolone $(0.5 \mathrm{mg} / \mathrm{kg} /$ day for 14 days followed by 7 days without treatment and with a schedule repeat). Squire et al. (1973) also reported remission times of $14-210$ days with administration of $2 \mathrm{mg} / \mathrm{kg} / \mathrm{d}$ for 7 days, then $1 \mathrm{mg} / \mathrm{kg} / \mathrm{d}$ thereafter in 20 dogs (41\%) who achieved remission for a mean of 53 days (range 14-210 days). In the latter paper they excluded patients who failed to survive 14 days so their median remission time is likely to be lower than their reported mean suggests. In addition Squire et al. (1973) do not report overall survival time however it can be assumed that this is longer than remission time. The single relevant case reported by Tozon et al. (2006) survived 240 days with Stage 3a lymphoma. The most recent publication (Valli et al., 2013) suggests that there is no benefit of treatment with prednisolone alone in a number of histological types and grades of lymphoma.

Clearly more research is required to review survival times of dogs with lymphoma who are given no treatment of any sort and comparing them to those receiving a standardised regime of prednisolone without prior other treatments and no further treatment of any sort being applied at a later date.

\section{Methodology Section}

\begin{tabular}{|c|c|}
\hline $\begin{array}{r}\text { Databases searched and dates } \\
\text { covered: }\end{array}$ & $\begin{array}{l}\text { CAB Abstracts (1973-week } 32 \text { 2017) and PubMed NCBI (1968- } \\
\text { August 2017) }\end{array}$ \\
\hline Search terms: & $\begin{array}{l}\text { CAB Abstracts } \\
\qquad \begin{array}{ll}1 & \text { (lymphoma* or lymphosarcoma*).mp. or lymphoma/ or } \\
\text { lymphosarcoma/ (CABI 14164) } \\
2 & \text { (dog or dogs or canine).mp. or dogs/ or canis/ (CABI 196531) } \\
3 & \begin{array}{l}\text { (glucocorticoid* or prednisolon* or prednison*or steroid* } \\
\text { or cortico-steroid* or corticosteroid).mp. or exp }\end{array} \\
& \begin{array}{l}\text { glucocorticoids/ or exp prednisolone/ or exp prednisone/ or } \\
\text { steroids/ or corticoids/ (CABi 69157) }\end{array} \\
4 & 1 \text { and } 2 \text { and } 3\end{array}\end{array}$ \\
\hline
\end{tabular}


1 dog or dogs or canine

2 glucocorticoid or prednisolone or prednisone or steroid or cortico-steroid or corticosteroid

3 lymphoma or lymphosarcoma

$4 \quad 1$ and 2 and 3

Dates searches performed: $\quad 23 / 08 / 2017$

\section{Exclusion / Inclusion Criteria}

Exclusion:

- Wrong species,

- Not lymphoma,

- In vitro studies,

- T cell lymphoma or wrong location of B cell lymphoma,

- No treatment reported

- Only chemotherapy or other treatments reported

- No survival data reported

- Reviews of other reported literature

- Letters to editor

- Conference proceedings with no abstract available

- Available in English

Inclusion: Correct species, B cell lymphoma with group treated with prednisolone alone and survival data reported in any form

\begin{tabular}{|c|c|c|c|c|c|c|}
\hline Database & $\begin{array}{l}\text { Number } \\
\text { of } \\
\text { results }\end{array}$ & $\begin{array}{c}\text { Excluded - not } \\
\text { relevant to PICO } \\
\text { question }\end{array}$ & $\begin{array}{l}\text { Excluded - } \\
\text { No survival } \\
\text { data } \\
\text { reported }\end{array}$ & $\begin{array}{c}\text { Excluded - } \\
\text { Reviews and } \\
\text { letters }\end{array}$ & $\begin{array}{c}\text { Excluded - } \\
\text { not in English } \\
\text { or not } \\
\text { available }\end{array}$ & $\begin{array}{c}\text { Total } \\
\text { relevant } \\
\text { papers }\end{array}$ \\
\hline $\begin{array}{l}\text { CAB } \\
\text { Abstracts }\end{array}$ & 260 & 231 & 1 & 7 & 17 & 4 \\
\hline PubMed & 201 & 194 & 1 & 3 & & 3 \\
\hline
\end{tabular}




\section{CONFLICT OF INTEREST}

The author declares no conflict of interest.

\section{REFERENCES}

1 Brick J., Roenigk, W. and Wilson, G. (1968) Chemotherapy of malignant lymphoma in dogs and cats. Journal of the American Veterinary Medical Association 153 (1) 47-52

2 Mortier,F., Daminet, S., Vandenabeele, S. et al. (2012) Canine lymphoma: a retrospective study (2009-2010). Vlaams Diergeneeskundig Tijdschrift 81 (6) 341-351

3 Squire, R., Bush, M., Melby, E. et al. (1973) Clinical and pathological study of canine lymphoma: clinical staging, cell classification and therapy. Journal of the National Cancer Institute, 51 (2), 56574

4 Tozon, N., Samardzija, P., Prijic, S. et al (2006) Canine lymphoma: cytologic study and response to therapy. Slovenian Veterinary Research 43 (3) 127-133

5 Valli, V., Kass P., San Myint, M. et al. (2013) Canine lymphomas: association of classification type, disease stage, tumor type, disease stage, tumor subtype, mitotic rate, and treatment with survival. Domestic Mammal Disease 50 (5) 738-748 DOI: http://dx.doi.org/10.1177/0300985813478210 


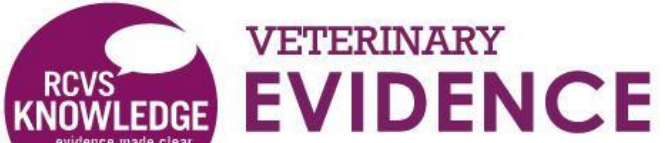 \\ ochese}

\section{Intellectual Property Rights}

Authors of Knowledge Summaries submitted to RCVS Knowledge for publication will retain copyright in their work, and will be required to grant to RCVS Knowledge a non-exclusive license of the rights of copyright in the materials including but not limited to the right to publish, re-publish, transmit, sell, distribute and otherwise use the materials in all languages and all media throughout the world, and to license or permit others to do so.

\section{Disclaimer}

Knowledge Summaries are a peer-reviewed article type which aims to answer a clinical question based on the best available current evidence. It does not override the responsibility

of the practitioner. Informed decisions should be made by considering such factors as individual clinical expertise and judgement along with patient's circumstances and owners' values. Knowledge Summaries are a resource to help inform and any opinions expressed within the Knowledge Summaries are the author's own and do not necessarily reflect the view of the RCVS Knowledge.

Veterinary Evidence and EBVM Network are RCVS Knowledge initiatives. For more information please contact us at editor@veterinaryevidence.org

RCVS Knowledge is the independent charity associated with the Royal College of Veterinary Surgeons (RCVS). Our ambition is to become a global intermediary for evidence based veterinary knowledge by providing access to information

that is of immediate value to practicing veterinary professionals and directly contributes to evidence based clinical decision-making.

www.veterinaryevidence.org

RCVS Knowledge is a registered Charity No. 230886. Registered as a Company limited by guarantee in England and Wales No. 598443.

Registered Office:

Belgravia House

62-64 Horseferry Road

London SW1P 2AF 